\author{
dr Anna Kizińska \\ Uniwersytet Warszawski \\ Wydział Lingwistyki Stosowanej, Katedra Ukrainistyki \\ tel. (22) 5534252 \\ e-mail: anna.kizinska@uw.edu.pl \\ ORCID ID: https://orcid.org/0000-0002-9775-1251
}

\title{
TRANSLATION METHODS FOR DEALING WITH THE INCONGRUITY OF CRIMINAL LAW TERMS IN THE POLISH AND BRITISH LEGAL SYSTEMS - A CASE STUDY ${ }^{1}$
}

\begin{abstract}
The research aims to discuss incongruent Polish and British terms referring to criminal law. British terms refers to terms characteristic of each of the three separate legal systems: England and Wales, Scotland, and Northern Ireland. The Polish terms under analysis appear in the Polish Criminal Code Act of 6 June 1997 (Journal of Laws 1997 No. 88 item 553) and constitute legal terms according to the definition by Morawski (1980: 187). The English equivalents of each Polish term researched appear in four Polish Criminal Code translations into English. The research problem is to verify whether the published typology of translation methods used in the Polish-English translation of succession and family law terms (which are civil law terms) (Kizińska 2018: 247-251) encompasses translation methods applied when translating criminal law terms into English. The translation methods are defined according to Hejwowski (2004: 76). The theoretical part of the paper includes a presentation of the definitions of a term (Zmarzer, Lukszyn 2001: 9) and incongruity of terms (Šarčević 1989: 278).
\end{abstract}

Key words: translation methods, equivalence, incongruent terms, Polish criminal law terms

\section{ABSTRAKT}

\section{METODY TłUMACZENIOWE STOSOWANE W TłUMACZENIU TERMINÓW NIEPRZYSTAJQ̨CYCH PRAWA KARNEGO (PRAWO BRYTYJSKIE I POLSKIE) - STUDIUM PRZYPADKU}

Badanie ma na celu omówienie polskich i brytyjskich nieprzystających terminów prawa karnego. Terminami brytyjskimi nazywane sq̨ terminy charakterystyczne dla trzech różnych systemów prawa, Anglii i Walii, Szkocji i Irlandii Północnej. Analizowane terminy polskie występują w treści polskiego kodeksu karnego (Dz. U. 1997 nr 88 poz. 553) i sq̨ terminami

1 Artykuł został opracowany w ramach realizacji projektu Miniatura 2 o numerze rejestracyjnym 2018/02/X/HS2/01602 finansowanego przez Narodowe Centrum Nauki. 
prawnymi zgodnie z definicją Morawskiego (1980: 187). Angielskie ekwiwalenty danego polskiego terminu pochodzą z opublikowanych czterech różnych łłumaczeń polskiego kodeksu karnego na język angielski. Celem badania jest zweryfikowanie tezy, zgodnie którą opublikowana klasyfikacja metod tłumaczeniowych (Kizińska 2018: 247-251) stosowanych w przekładzie polskich terminów prawa spadkowego i rodzinnego (czyli prawa cywilnego) na angielski znajdzie zastosowanie w przekładzie terminów prawa karnego na język angielski. Metody przekładowe są tu definiowane za Hejwowskim (2004: 76). Część teoretyczna obejmuje definicję terminu (Zmarzer, Lukszyn 2001: 9) and nieprzystawalności terminów (Šarčević 1989: 278).

Słowa kluczowe: metody łłumaczeniowe, ekwiwalencja, terminy nieprzystające, terminy polskiego prawa karnego

\section{Introduction}

The translation of terms characteristic for a legal system (called systembound terms by Šarčević ${ }^{2}$ ) is in general an extremely challenging activity, as it is time-consuming to find the most accurate equivalent. As far as PolishEnglish and English-Polish translation is concerned, it is even more arduous to find the most accurate equivalent as the Polish legal system belongs to a civil law system, while the British legal system is an example of a common law system. It should be emphasised that the United Kingdom of Great Britain and Northern Ireland has no unified legal system. England and Wales have one common legal system, while Scotland and Northern Ireland have separate legal systems. In this paper the terms used to name the legal institutions of the legal systems of England and Wales, Scotland, and Northern Ireland are called British legal system terms.

In 2018, a typology of translation methods used in the Polish-English translation of succession and family law terms (which are civil law terms) was published $^{3}$. The research problem is to verify whether the typology of translation methods encompasses translation methods applied when translating criminal law terms into English. It should be emphasized that the classification mentioned is merely one of quite a few typologies of translation methods used in the translation of legal terms that have been published globally - Covacs ${ }^{4}$,

2 S. Šarčević, New Approach to Legal Translation, The Hague-London-Boston 1997, s. 232.

3 A. Kizińska, Polskie i angielskie terminy nieprzystajace. Prawo rodzinne i spadkowe, Warszawa 2018, s. $247-251$

4 A. Covacs, La réalisation de la version francaise des lois fédérales du Canada, [w:] Langage du droit et traduction, J. C. Gémar (red.), Montréal 1982, s. 83-100. 
Weston $^{5}$, Harvey ${ }^{6}$. The classification by Kizinska was chosen for the research project as this classification was granted approval to be carried out by the decision of the National Science Centre Poland on 18 October 2018. The project in question aims at verifying whether the classification is valid for the translation of criminal law terms into English, as the classification was initially formulated on the basis of research into civil law terms. The project encompasses the analysis of fifty Polish criminal law terms and their English equivalents. Five of the Polish terms discussed serve as the first research sample to preliminarily verify the thesis formulated herein. It should be added that the British legal system is taken as a point of reference in this research, as the above typology of methods was formulated as a result of research where that legal system was the point of reference.

\section{Survey of literature}

The Polish criminal law terms under analysis are all assumed to be terms in accordance with the definition of a term by Sager": "The items which are characterised by special reference within a discipline are the terms of that discipline (...)", as well as the definition of a term by Lukszyn and Zmarzer: "a word (a phrase) of a conventionally determined, strictly defined conceptual structure, as a rule monosemic and uninterpretable, of an emotional character, able to create systems ${ }^{\prime \prime}$. The discussed terms constitute legal terms according to the division of terms by Morawski ${ }^{9}$ : who defines them as terms occurring in teksty prawne, all the application criteria of which are defined by the law and expressed by legal definitions - classical or partial. By contrast, an actual term is a term the application criteria of which are not formulated in tekst prawny ${ }^{10}$. Teksty prawne are understood in this paper according to Gizbert-Studnicki as normative texts ${ }^{11}$. The Polish terms under analysis appear in the Polish Criminal Code Act of 6 June 1997 (Journal of Laws 1997 No. 88 item 553). The English

5 M. Weston, An English reader's guide to the French legal system, Providence, Oxford 1993, s. 41-51.

6 M. Harvey, A beginner's course in legal translation: The case of culture-bound terms, 2003, s. 1-9, [online], http://www.tradulex.com/Actes2000/harvey.pdf, [dostęp 18.07.2019].

7 J. C. Sager, Practical Course in Terminology Processing, Amsterdam, 1990, s. 19.

8 J. Lukszyn, W. Zmarzer, Teoretyczne podstawy terminologii, Warszawa 2001, s. 9.

9 L. Morawski, O pewnym rozumieniu prawa i faktu oraz o niektórych jego zastosowaniach, "Ruch Prawniczy, Ekonomiczny i Socjologiczny" 1980, 1, s. 187.

10 Ibidem.

11 T. Gizbert-Studnicki, Język prawny z perspektywy socjolingwistycznej, "Zeszyty Naukowe Uniwersytetu Jagiellońskiego. Prace z nauk politycznych" 1986, 26, s. 95-102. 
equivalents of each Polish term researched appear in four Polish Criminal Code Act translations into English: Kodeks karny The Penal Code, translated by Ewa Łozińska-Małkiewicz, Torun 2008; The Criminal Code, bilingual edition, translated by Nicholas Faulkner, Warszawa 2012; Kodeks karny Criminal Code przepisy dwujezyczne, edited by Włodzimierz Wróbel, translated by Adam Wojtaszczyk, Witold Zontek, Warszawa 2014, and the text of the translation available in the legislationline.org free-of-charge online legislative database created to assist the Organisation for Security and Cooperation in Europe participating States in bringing their legislation into line with relevant international human-rights standards (https://www.legislationline.org).

The stages of the research include: 1) the presentation of a definition of a Polish term (that comes from an updated criminal code coursebook, or the Criminal Code), 2) an enumeration of the English equivalents of the given Polish term published to date and a comparison of their definitions (as they appear in English law dictionaries: Jowitt's Dictionary of English Law 4th edition, 2015, Osborn's Concise Law Dictionary 2001, Dictionary of Law 2002, A Dictionary of Law 2003 with the definition of the given Polish term under analysis), 3) checking whether or not an English equivalent appears in the sources of British law, namely the legislation.gov.uk database, which carries most types of legislation and their accompanying explanatory documents, and the English language in general (corpora of sketchengine.eu, which contains five hundred ready-to-use corpora in over ninety languages, each having a size of up to thirty billion words), and 4) identifying the translation method that has been applied when forming the English equivalent. The translation methods are defined according to Hejwowski ${ }^{12}$ as: a given type of action undertaken during the translation process, as well as the given translation solution, the implementation of which may be evaluated directly in the target text $\mathrm{t}^{13}$.

\section{Methods of translation}

As soon as the translation methods have been determined, it is possible to verify whether the published typology of translation methods used in the translation of incongruent Polish and English civil law terms encompasses the translation methods applied when translating criminal law terms into English. The typology mentioned classifies methods as follows: 1) the functional equivalent method by Hejwowski, which involves replacing the name of a phe- 
nomenon (or a reference thereto) which is more commonly known in the source culture with the name of a phenomenon (a reference thereto) which is more commonly known in the target culture; 2 ) the hypernym method involves replacing a hyponym in the source text with a hypernym in the target text; 3) the hyponym method involves replacing a hypernym in the source text with a hyponym in the target text; 4) the descriptive equivalent method by Hejwowski involves replacing a term with a description or a definition; 5) the partial semantic shift method involves using a phrase from the target language in the target text that appears in the texts of the sources of law of the target language, the meaning of which is partially different from the meaning of the phrase from the source language that appears in the texts of the sources of law of the source language. As a result, the meaning of the phrase of the target language in the target text is partially changed; 6) the complete semantic shift method involves using a phrase from the target language in the target text that appears in the texts of the sources of law of the target language, the meaning of which is completely different from the meaning of the phrase from the source language that appears in the texts of the sources of law of the source language. As a result, the meaning of the phrase of the target language in the target text is changed; 7) the terminologisation method involves using in the target text a phrase that appears in the target language but is not a legal term. The result of its application means a phrase of general language becoming a legal term in the target language; an equivalent appears in English texts but does not signify a legal institution; 8) the calque method, which encompasses the calque method or procedure by Vinay and Darblenet ${ }^{14}$, the translation procedure by Newmark ${ }^{15}$ called the calque, as well as partially the calque and loan strategies by Chester$\operatorname{man}^{16}$. As a result, new phrases that do not appear in the target language are formed ${ }^{17}$; 9) the transposition method, which involves replacing one part of speech with another; 10) the translation doublet involves a) replacing a source term with two descriptive equivalents in the target text (the second of the descriptive equivalents used is in round brackets in the target text); or b) replacing a source term with two equivalents in the target text that have been formed with the application of two methods where the second equivalent (that is in round or square brackets, or partially in round brackets) has been formed with

14 J.-P. Vinay, J. Darbelnet, A methodology for translation, [w:] The Translation Studies Reader, L. Venuti (red.), London-New York 1958/2000, s. 85.

15 P. Newmark, A textbook of translation, New York-London 1988, s. 70.

16 A. Chesterman, Memes of translation: the spread of ideas in translation theory, Amsterdam 1997, s. 89-91.

17 A. Kizińska, Ekwiwalencja w tłumaczeniu tekstów prawnych i prawniczych. Polskie $i$ brytyjskie prawo spadkowe, Warszawa 2015, s. 159. 
the application of the functional equivalent method or descriptive equivalent method; 11) the recognized translation method by Newmark ${ }^{18}$, which is of secondary character in comparison with methods $1-9$, as each equivalent to be widely used (and thus acquiring the status of a recognized translation) must have been formed with the application of one or more of methods 1-919. With reference to the above-mentioned functional equivalent method, it should be emphasised that the term functional equivalent is defined in translation studies in different ways (e.g. Reiss and Vermeer 1984). The definition by Šarčević is: "a term designating a concept or institution of the target legal system having the same function as a particular concept of the source legal system" ${ }^{20}$. Finding a functional equivalent is the first step in the decision-making process ${ }^{21}$. "In order to determine the acceptability of a functional equivalent, translators must compare the target and source concepts to establish their degree of equivalence"22. It is worth mentioning that in the literature numerous advantages and disadvantages of using these two techniques have been listed and discussed ${ }^{23}$, but it is the translator who finally decides, taking into account, first of all, the potential recipients of the text and its function.

\section{Working method}

In this paper, five legal terms randomly excerpted from the text of the Polish Criminal Code Act of 6 June 1997 (Journal of Laws 1997 No. 88 item 553) that have been proved not to have a one-to-one equivalent in Polish code translations into English published to date are to be subjected to analysis. The above-mentioned five conceptually incongruent terms are interpreted as defined by Šarčević ${ }^{24}$. "Due to the conceptual incongruency of terminology of different legal systems, it is sometimes extremely difficult to select equivalents that will guarantee uniform interpretation and application of the propositional content of a legal norm" 25 . s. $247-251$.

Ibidem.

P. Newmark, A textbook of translation..., s. 92.

A. Kizińska, Polskie $i$ angielskie terminy nieprzystające. Prawo rodzinne $i$ spadkowe, Warszawa 2018,

S. Šarčević, New Approach to Legal..., s. 236.

L.-P. Pigeon, La rédaction bilingue des lois fédérales, "Revue générale de dront" 1982, 13, s. 177-186; za: S. Šarčević, New Approach to Legal..., s. 236.

E. Alcaraz, B. Hughes, Legal Translation Explained, Manchester 2002, s. 178-179; za : A. JopekBosiacka, Przekład prawny $i$ sądowy, Warszawa 2008, s. 51.

24 S. Šarčević, New Approach to Legal..., p. 232.

5 Ibidem, s. 149. 
The concept of equivalence is closely connected with the phenomenon of incongruity of terms, i.e. non-coincidence of their semantic fields. The legal terminology characteristic of different legal systems is to a large extent conceptually incongruent ${ }^{26}$. Moreover, Jopek-Bosiacka ${ }^{27}$ states that the multitude of legal systems is often the source of non-equivalence of concepts, or non-coincidence of semantic fields of terms.

\section{Analysis}

The table below presents the Polish terms under analysis and their English equivalents. The Polish criminal law terms have been extracted from the Polish Criminal Code, chosen randomly among numerous Polish terms that are highly likely to have similar but not fully congruent terms in the target legal system. The five Polish terms discussed serve as the first research sample, as it is planned to analyse at least fifty Polish terms to verify the thesis formulated herein.

Table 1. Polish terms and their equivalents

\begin{tabular}{|l|l|l|l|l|}
\hline \multicolumn{1}{|c|}{ Polish term } & $\begin{array}{l}\text { Lozińska-Ma1- } \\
\text { kiewicz (2008) }\end{array}$ & $\begin{array}{c}\text { legislation. } \\
\text { online.org }\end{array}$ & Faulkner (2012) & $\begin{array}{l}\text { Wojtaszczyk } \\
\text { Zontek (2014) }\end{array}$ \\
\hline $\begin{array}{l}\text { kradzież } \\
\text { z włamaniem }\end{array}$ & $\begin{array}{l}\text { theft by } \\
\text { breaking }\end{array}$ & burglary & burglary & $\begin{array}{l}\text { larceny by } \\
\text { breaking }\end{array}$ \\
\hline $\begin{array}{l}\text { ograniczenie } \\
\text { wolności }\end{array}$ & $\begin{array}{l}\text { restriction of } \\
\text { freedom }\end{array}$ & $\begin{array}{l}\text { restriction of } \\
\text { liberty }\end{array}$ & $\begin{array}{l}\text { restriction of } \\
\text { liberty }\end{array}$ & $\begin{array}{l}\text { limitation of } \\
\text { liberty }\end{array}$ \\
\hline $\begin{array}{l}\text { praca na cele } \\
\text { społeczne }\end{array}$ & $\begin{array}{l}\text { work for the } \\
\text { good of others }\end{array}$ & $\begin{array}{l}\text { work for } \\
\text { community } \\
\text { purposes }\end{array}$ & $\begin{array}{l}\text { community } \\
\text { work }\end{array}$ & $\begin{array}{l}\text { work for } \\
\text { community }\end{array}$ \\
\hline nawiązka & $\begin{array}{l}\text { compensatory } \\
\text { damages }\end{array}$ & $\begin{array}{l}\text { supplementary } \\
\text { payment }\end{array}$ & $\begin{array}{l}\text { monetary } \\
\text { performance } \\
\text { exemplary } \\
\text { damages }\end{array}$ & $\begin{array}{l}\text { punitive } \\
\text { damages }\end{array}$ \\
\hline $\begin{array}{l}\text { stan wyższej } \\
\text { konieczności }\end{array}$ & $\begin{array}{l}\text { state of } \\
\text { necessity }\end{array}$ & $\begin{array}{l}\text { necessary } \\
\text { defence }\end{array}$ & $\begin{array}{l}\text { protective force } \\
\text { patate of } \\
\text { necessity }\end{array}$ \\
\hline
\end{tabular}

\footnotetext{
26 Ibidem, s. 278.

27 A. Jopek-Bosiacka, Przekład prawny i sadowy, Warszawa 2008, s. 51.
} 


\section{kradzież z włamaniem}

The first term under analysis is kradziez $z$ wtamaniem. According to its definition, the legal institution mentioned bears the hallmarks of a theft (kradziez $z w y k t a)$, which involves an act of willfully taking someone else's movable property with the purpose of appropriating it, and additionally involves breaking in. Kradziez z z wamaniem is an attack on the same property as kradzież zwykła but constitutes a crime regardless of the value of a stolen good, in contrast to kradziez $z w y k ł a{ }^{28}$. According to Article $279 \S 1$ of the Polish Criminal Code: "whoever commits a burglary shall be subject to the penalty of deprivation of liberty for a term of between 1 and 10 years" ${ }^{\prime 2}$. The first equivalent used, burglary, appearing in the texts of sources of British law, is defined as follows: "Under Th.A. $1969 \mathrm{~s} 9$ (1), a person is guilty of burglary if 'he enters any building or part of a building as a trespasser, and with the intent to commit any such offence as mentioned in sub-s (2) [stealing, inflicting grievous bodily harm, etc.]; or having entered any building or part of it, inflicts or attempts to inflict on any person therein any grievous bodily harm" ${ }^{\prime 30}$. According to A Dictionary of Law $w^{31}$, the offence involves "entering a building, ship, or inhabited vehicle as a trespasser with the intention of committing one of four specified crimes in it (burglary with intent), or entering it as a trespasser only but subsequently committing one of two specified crimes in it (burglary without intent). The four specified crimes for burglary with intent are (1) theft; (2) inflicting bodily harm; (3) causing criminal damage; and (4) rape of a person in the building. The two specified offences for burglary without intent are (1) stealing or attempting to steal; and (2) inflicting or attempting to inflict grievous bodily harm. Burglary is punishable by up to 14 years' imprisonment". Taking the quoted definitions into account, it may be assumed that the semantic fields of the Polish term and the English equivalent under analysis partially coincide, as they both name a crime that involves trespassing (unlawful entry) and stealing goods. On the other hand, the meaning of the suggested equivalent is indisputably more extensive as it may encompass inflicting grievous bodily harm and rape, thus it has probably been formed as a result of the application of the hypernym method. nal-codes/country/10, [dostęp: 15.07.2019].

30 L. Curzon, Dictionary of Law, New York 2002, s. 52.

31 A Dictionary of Law, Oxford 2003, s. 60. 
Another equivalent of the term kradziez $z$ włamaniem is larceny by breaking. The equivalent does not appear in the sources of British law or legal dictionaries. The term larceny, however, is defined as: "Formerly, before 1969, theft. Larceny was more limited than theft and required an asportation (carrying away of the property)" ${ }^{\prime \prime 2}$. In the Larceny Act 1916 the term in question is understood as: "For the purposes of this Act - (1) A person steals who, without the consent of the owner, fraudulently and without a claim of right made in good faith, takes and carries away anything capable of being stolen with intent, at the time of such taking, permanently to deprive the owner thereof: Provided that a person may be guilty of stealing any such thing notwithstanding that he has lawful possession thereof, if, being a bailee or part owner thereof, he fraudulently converts the same to his own use or the use of any person other than the owner: (2) - (i) the expression 'takes' includes obtaining possession - (a) by any trick; (b) by intimidation; (c) under a mistake on the part of the owner with knowledge on the part of the taker that possession has so been obtained; (d) by finding, where at the time of the finding the finder believes that the owner can be discovered by taking reasonable steps; (ii) the expression 'carries away' includes any removal of anything from the place which it occupies, but in the case of a thing attached, only if it has been completely detached; (iii) the expression 'owner' includes any part owner, or person having possession or control of, or a special property in, anything capable of being stolen". On the basis of the definitions it may be assumed, first of all, that larceny does constitute a hyponym of the Polish term, as they both refer to a crime that involves taking away anything capable of being stolen with intent, but the Polish crime involves breaking in. Summing up, larceny by breaking has been formed as a result of the application of the hyponym method and a descriptive equivalent (by breaking). The descriptive element referring to the fact of trespassing in order to steal has presumably been added to make the semantic fields of the source term and its equivalent coincide to a larger extent. The equivalent theft by breaking includes the term theft defined as "the dishonest appropriation of property belonging to someone else with the intention of keeping it permanently. 'Appropriation' is defined in the Theft Act 1968 as the assumption of the rights of the owner or the property, and includes any act showing that one is treating the property as one's own, which need not necessarily involve taking it away (...) 'Property' includes all tangible and intangible objects and choses in action $(. . .)^{33}$. As the Polish term refers to the appropriation of property and

32 Ibidem, s. 280.

33 Ibidem, s. 497. 
theft - appropriation of property and rights, the equivalent is a hypernym of the source term. Apart from the hypernym method having been used to form the equivalent in question, the descriptive equivalent method has also been applied, since the element by breaking, similarly to the equivalent discussed above, has been added during the process of translation.

\section{ograniczenie wolności}

The second term under analysis is ograniczenie wolności defined (in the Polish Criminal Code, Article 34) as follows: "Unless otherwise provided by law, the penalty of restriction of liberty shall be not less than one month and not more than 12 months; it is imposed in terms of months. While serving the penalty of restriction of liberty, the sentenced person: 1) may not change his permanent place of residence without the permission of the court, 2) shall be obliged to perform work designated by the court, 3) shall be obliged to provide explanations regarding the progress of terms of serving the penalty" ${ }^{\prime 34}$. The suggested equivalents are: restriction of liberty and limitation of liberty. The terms have not been accommodated as entries in legal dictionaries. Nevertheless, the equivalent restriction of liberty appears in the titles of British texts of sources of law and is defined in Section 245 (A) of the Crime and Punishment (Scotland) Act 1997: "(2) A restriction of liberty order may restrict the offender's movements to such extent as the court thinks fit and, without prejudice to the generality of the foregoing, may include provision - (a) requiring the offender to be in such place as may be specified for such period or periods in each day or week as may be specified; (b) requiring the offender not to be in such place or places, or such class or classes of place or places, at such time or during such periods, as may be specified, but the court may not, under paragraph (a) above, require the offender to be in any place or places for a period or periods totalling more than 12 hours in any one day. (3) A restriction of liberty order may be made for any period up to 12 months. (...)". It should be emphasised that both suggested equivalents appear in English language corpora. Taking the above definitions into account, it may be assumed that the equivalent $r e-$ striction of liberty does constitute a functional equivalent of the Polish term in question as they both name a legal institution, namely a type of punishment the pronouncement of which involves restricting the rights of an offender, such as: requiring an offender to be in given places, as well as requiring them not

34 Polish Criminal Code translation into English copied from: www.legislationline.org/documents/ section/criminal-codes/country/10, [dostęp: 15.07.2019]. 
to be in given places. What is more, another common element of the Polish and British legal terms being discussed is the fact that the punishment may be pronounced for up to 12 months. Still, they are incongruent, as their semantic fields differ significantly. The Polish punishment, for example, involves the duty of an offender to perform unpaid work for the community. The equivalents limitation of liberty and restriction of freedom, on the other hand, do not appear in the texts of the sources of British law. They may be assumed to have been formed by the calque method, as they do not appear in English language corpora, either.

\section{praca na cele społeczne}

The third Polish term under analysis is praca na cele spoteczne. The term names one of the limitations an offender experiences as a result of kara ograniczenia wolności having been pronounced. It is defined as a duty to do supervised work for community purposes without remuneration for 20 to 40 hours a month, in a suitable establishment, health service or social welfare unit, organisation or institution conducting charity work or work for the purposes of community work (Article $35 \S 1$ ). The suggested equivalents are community work, work for community, work for the good of others and work for community purposes. The first equivalent appears in the sources of British law revealing various meanings, including work by an offender: "134. If you are eligible, and choose to take part in the Armed Forces Victim Contact Scheme, you are entitled to the information set out in this paragraph only where there is a danger or an identified risk of harm to you, in which case the information will be provided without unnecessary delay (1): (1) (...); (2) (...); (3) receive information from the Military Corrective Training Centre without unnecessary delay about the offender's Short Term Temporary Release, Re-Integration Leave, Compassionate Leave, transfer to open conditions, release on licence, or Community Work placements, or final release; (...) (The Criminal Justice Regulations 2015, section: Armed Forces Victim Contact Scheme)." In another context [The Education (Prescribed Courses of Higher Education) (Information Requirements) (England) Regulations 2015; Schedule] the equivalent under discussion is the name of a subject taught in higher education. The equivalent has probably been formed as a result of the application of the hypernym method, as it has a more extensive meaning than the Polish source term.

The equivalents work for community, and work for community purposes do not appear in British legal system texts or English language corpora, and are presumably calques of the Polish term, while work for the good of others may have been formed with a descriptive equivalent method, as it explains the meaning 
of the source term rather than representing each of its elements in the form of a word-for-word translation.

Nevertheless, the most accurate functional equivalent (for the Polish term discussed) suggested in this paper is community punishment as, according to the definition of community punishment order, accommodated in a legal dictionary ${ }^{35}$, 'community punishment order' $=$ an order requiring an offender to do unpaid work for the community. Formerly known as a community service order, Powers of Criminal Courts".

\section{nawiązka}

Another Polish term discussed is nawiazka, and the equivalents published to date are: monetary performance, exemplary damages, punitive damages, supplementary payment, and compensatory damages. It should be emphasised that in the English translation of the Polish Criminal Code by Faulkner (2002) two different equivalents (monetary performance, exemplary damages) have been used to translate one source term.

The term nawiazka names a repressive-compensatory legal measure (usually pronounced along with the main punishment) involving the obligation to pay a given amount of money to the injured party or a social organisation. The nawiazka legal measure is usually pronounced in order to compensate for grievous bodily harm, disruption of the work of an organ, or health disorder, and is a substitute for remedying damage in particular in a situation where it is extremely difficult or impossible to determine the value of the damage (gazetaprawna.pl). The equivalent monetary performance has neither been accommodated by legal dictionaries, nor appears in English language corpora. Presumably, the equivalent in question has been formed as a result of the application of the calque method.

The equivalent punitive damages as a synonym of the term exemplary damages is defined as: "Damages given to punish the defendant rather than (or as well as) to compensate the plaintiff for harm done. Such damages are exceptional in tort, since the general rule is that damages are given only to compensate for loss caused. They can be awarded in some tort actions: (1) when expressly authorised by statute; (2) to punish oppressive, arbitrary, or unconstitutional acts by government servants; (3) when the defendant has deliberately calculated that the profits to be made out of committing a tort may exceed the damages at risk" ${ }^{\prime \prime 6}$. The equivalent presumably serves as a functional equivalent of the

\footnotetext{
35 S. Bone, Osborn's Concise Law Dictionary, London, 2001, s. 91.

36 A Dictionary of Law, Oxford 2003, s. 191.
} 
Polish term as they both name a legal measure involving an obligation to pay money to the injured party. It should be underlined that the Polish and English terms belong to different branches of law. Under the Polish legal system, the Polish one is a criminal law term and the English one is an element of British tort law, that is a part of British private law, where the British criminal law branch is an element of British public law. The equivalent supplementary payment does appear in texts of British law in various meanings. As an element of the phrase "welfare supplementary payment" it is interpreted as an allowance in, inter alia, The Welfare Supplementary Payment (Loss of Disability Living Allowance) Regulations (Northern Ireland) 2016, or defined as a "payment of less favoured area support made under regulation 5 to an applicant who has already applied for payment in accordance with regulation 3 under Scheme 2006 and has been paid a Scheme 2006 payment in accordance with regulation 5" in The Less Favoured Area Support Scheme (Scotland) Amendment Regulations 2006. As the equivalent in question has acquired various meanings in texts of law (UK) which are, however, different from the semantic field of the Polish source term, it has probably been formed as a result of the application of the complete semantic shift method. The last equivalent, compensatory damages, does not appear in the legal dictionaries listed above (section: Methods used) but has been accommodated by Black's Law Dictionary and defined as: "Damages sufficient in amount to indemnify the injured person for the loss suffered" ${ }^{\prime 37}$. The equivalent is probably a functional equivalent of the source term, as the semantic fields of the source and target terms basically coincide (both name damages paid in order to compensate an injured entity) but are characteristic of two different branches of law. According to the Polish regulations, nawiazka is a criminal law term and the English term is an element of British tort law, that is part of British private law, where the British criminal law branch is an element of British public law. It should be emphasised that in this very case the definition of the equivalent has been taken from a United States dictionary of law (Black's Law dictionary) as the term has not been included in the British legal dictionaries listed in the Survey of Literature section.

\section{stan wyższej konieczności}

The last Polish term under discussion is stan wyższej konieczności, defined as a circumstance under which the exclusion of guilt occurs in a situation where any good protected by law is threatened by immediate danger that may be elimi- 
nated exclusively by sacrificing another good protected by the law (the principle of subsidiarity), but that the sacrificed good represents the same or lower value than the one being saved (the principle of proportionality) ${ }^{38}$. It should be added that "If the limits of stan wyższej konieczności have been exceeded, the court may apply an extraordinary mitigation of the penalty, and even refrain from imposing it" (Article $26 \S 3$ ). The suggested equivalents are: protective force, state of necessity and necessary defence; the first two do not appear in texts of the sources of British law, and the last one appears exclusively as an element of the following context of the Bank of England Act 1694: "Wee your Majesties most dutifull and loyall Subjects the Comons assembled in Parliament for the further Supply of your Majesties extraordinary Occasions for and towards the necessary Defence of your Realmes doe humbly present your Majesties with the further Gift of the Impositions Rates and Duties herein after mentioned: (...)" where it is presumably just a phrase, not a term. The equivalents discussed do not appear in legal dictionaries; nevertheless, the term necessity has been accommodated in legal dictionaries ("The invasion of the private rights of others may possibly be justified and defended on the grounds of necessity. (...) Necessity may be an excuse for committing what would otherwise be a criminal offence if the act or omission which is in question was necessary to prevent the execution of an illegal purpose."; $; 9$ "pressure of circumstances compelling one to commit an illegal act. The extent to which English law accepts a defence of necessity to a criminal charge is unclear (...). Necessity is in some circumstances a defence to an action in tort, but it is probably limited to action taken to protect life or property in an emergency not caused by the defendant's negligence (...)" "in the law of tort the defence may succeed where the damage has been caused to prevent a greater evil and the act was reasonable"41. On the basis of the definitions it may be stated that stan wyższej konieczności and defence name a legal institution which constitutes an excuse for committing what would otherwise be a criminal offence, but they are incongruent, as the Polish terms belong to criminal law exclusively, and the legal institution named by the English term may be interpreted under both private and public law.

Coming back to the equivalents, as the phrases state of necessity and protective force do appear in English language corpora they are probably calques of the Polish source term, while the suggested equivalent necessary defence that appears in the English language corpora has presumably been formed by the process

\footnotetext{
38 A. Grześkowiak, K. Wiak, Prawo karne..., s. 147.

39 S. Bone, Osborn's Concise Law..., s. 261.

40 A Law Dictionary, Oxford 2003, s. 327.

41 L. Curzon, Dictionary of Law..., s. 284.
} 
of terminologisation, as it is a phrase of the English language but does not appear in the texts of British law or legal dictionaries. Still, the equivalent state of necessity includes the functional equivalent necessity discussed above.

\section{Conclusions}

To conclude, first of all, it must be stated that the above research constitutes a case study and is set to be continued so as to encompass around fifty Polish criminal law terms and their English equivalents published to date, to potentially present a typology of translation methods used in the translation of incongruent Polish and English criminal law terms. However, on the basis of the above discussion it may provisionally be presumed that the published typology of translation methods used in the translation of incongruent Polish and English civil law terms encompasses the translation methods applied when translating criminal law terms into English, as the equivalents under analysis have been formed as a result of the application of as many as seven out of the eleven methods of the typology. As many as seven calques have appeared (limitation of liberty, restriction of freedom, work for community, work for community purposes, monetary performance, state of necessity, protective force), and as many as four functional equivalents (exemplary damages, punitive damages, compensatory damages, restriction of liberty). There has been one case of the application of a complete semantic shift method (which involves using a phrase of the target language in the target text that appears in texts of the sources of law of the target language, whose meaning is completely different from the meaning of a phrase of the source language that appears in texts of the sources of law of the source language), exemplified by supplementary payment being the suggested equivalent for nawiazka. Furthermore, two equivalents, burglary and community work, have been used as a hypernym of the Polish source term in the target text. What is more, one equivalent appears, necessary defence, which is an English phrase that has acquired a specialist meaning in the target text during the translation process (terminologisation method). One descriptive equivalent has been formed (work for the good of others). It is worth mentioning that two equivalents, namely, larceny with breaking and theft with breaking, constitute a hyponym and hypernym of the Polish term, respectively, but as both have been accompanied by an explanatory element they constitute descriptive equivalents at the same time. It should be emphasised that for two Polish terms (praca na cele społeczne, nawiazka) four different English equivalents have been used in four publications. This may prove that translators compensate for lexical voids in different ways, as they are aware of the phenomenon of incongruity of terms. 
Moreover, for as many as two Polish terms, a new functional equivalent has been proposed in this paper, i.e. necessity for the Polish stan wyższej konieczności and community punishment for praca na cele społeczne.

\section{Bibliography}

Alcaraz E., Hughes B., Legal Translation Explained, Manchester 2002.

Chesterman A., Memes of translation: the spread of ideas in translation theory, Amsterdam 1997.

Covacs A., La réalisation de la version francaise des lois fédérales du Canada, [w:] Langage du droit et traduction, J. C. Gémar (red.), Montréal 1982, s. 83-100.

Faulkner N. (trans.),The criminal code, bilingual edition, Warszawa 2012.

Gizbert-Studnicki T., Język prawny z perspektywy socjolingwistycznej, "Zeszyty Naukowe Uniwersytetu Jagiellońskiego. Prace z nauk politycznych" 1986, 26, s. 95-102.

Harvey M., A beginner's course in legal translation: The case of culture-bound terms, 2008, s. 1-9, [online], http://www.tradulex.com/Actes2000/harvey.pdf, [dostęp: 18.07.2019].

Hejwowski K., Kognitywno-komunikacyjna teoria przekładu, Warszawa 2004.

Jopek-Bosiacka A., Przekład prawny i sadowy, Warszawa 2008.

Kizińska A., Ekwiwalencja w tłumaczeniu tekstów prawnych i prawniczych. Polskie i brytyjskie prawo spadkowe, Warszawa 2015.

Kizińska A., Polskie $i$ angielskie terminy nieprzystajace. Prawo rodzinne $i$ spadkowe, Warszawa 2018.

Lukszyn J., Zmarzer W., Teoretyczne podstawy terminologii, Warszawa 2001.

Łozińska-Małkiewicz E. (trans.), Kodeks karny The Penal Code, Toruń 2008.

Morawski L., O pewnym rozumieniu prawa i faktu oraz o niektórych jego zastosowaniach, "Ruch Prawniczy, Ekonomiczny i Socjologiczny" 1980, 1, s. 185-204.

Newmark P., A textbook of translation, New York-London 1988.

Pigeon L.-P., La rédaction bilingue des lois fédérales, "Revue générale de dront" 1982, 13, s. 177-186.

Reiss K., Vermeer H., Grundlegung einer allgemeinen Translationstheorie, Tübingen 1984. Šarčević S., New Approach to Legal Translation, The Hague-London-Boston 1997.

Conceptual dictionaries for translation in the field of law, "International Journal of Lexicography" 1989, 2/4, s. 277-293.

Vinay J.-P., Darbelnet J., A methodology for translation, [w:] The Translation Studies Reader, L. Venuti (red.), London-New York 1958/2000.

Weston M., An English reader's guide to the French legal system, Oxford 1993.

Wojtaszczyk A., Zontek W. (trans.), Kodeks karny Criminal Code przepisy dwujęzyczne, Warszawa 2014. 


\section{Legal acts}

Ustawa z dnia 6 czerwca 1997 r. - Kodeks karny. Criminal Code Act of 6 June 1997 (Journal of Laws 1997 No. 88 item 553).

Larceny Act 1916.

Crime and Punishment (Scotland) Act 1997.

Bank of England Act 1694.

\section{Websites}

Gazetaprawna.pl: https://www.gazetaprawna.pl/encyklopedia/prawo/hasla/33453 7,nawiazka.html, [dostęp: 06.01.2019].

Legislationonline.org: https://www.legislationline.org/documents/section/criminal-codes/cou ntry/10, [dostęp: 01.12.2018].

legislation.gov.uk [dostęp: 10.10.2019]. sketchengine.eu [dostęp: 10.12.2018].

\section{Dictionaries}

A Dictionary of Law, Oxford University Press 2003.

Black's Law Dictionary, Seventh Edition, Minnesota 1999.

Bone S.,Osborn's Concise Law Dictionary, London 2001.

Curzon L.,Dictionary of Law, New York 2002.

Jowitt's Dictionary of English Law, London 2015. 